This is the accepted version of an article published by Sage in Critical Sociology. Published version available at: https://doi.org/10.1177/0896920517715765

Accepted version downloaded from SOAS Research Online: http://eprints.soas.ac.uk/23775/

\title{
Polar opposites? NGOs, left parties and the fight for social change in Nepal
}

\author{
Feyzi Ismail, Department of Development Studies, SOAS University of London
}

\begin{abstract}
In the early 1990s, when NGOs were rising to prominence as an ostensible force for social change in Nepal, the Maoists were also beginning to organise, and denounced NGOs as agents of imperialism. The Maoists came to prominence by fighting a People's War launched in 1996, with the intention of improving life for the poor peasant and working-class majority. But after a decade-long struggle, the Maoists became incorporated into the parliamentary system. While Nepal's first democratic revolution in 1990 met formal, popular political demands, which were consolidated in a subsequent revolution in 2006 overthrowing the monarchy and bringing the People's War to an end, there was little socio-economic progress for the vast majority. The argument advanced in this article is that this lack of progress relied on the interplay of two phenomena: an anti-Maoist alliance consisting of the international community, the domestic ruling elite and NGOs, and a fundamental ambiguity at the heart of the Maoists' political theory.
\end{abstract}

Key words: Nepal; democratic revolution; NGOs; imperialism; social change

\section{Introduction}

The complex and contradictory relationship between non-governmental organisations (NGOs) and the left parties in Nepal, and their respective approaches to social change, is an understudied subject. Yet the nature of this relationship is crucial to understanding politics and development in Nepal since at least the end of the Cold War. In Nepal as elsewhere, the transition to the post-Cold War world was a moment of revolution, which overthrew the authoritarian panchayat system and restored multiparty politics under a constitutional monarchy. The experience of the 1990 revolution was significant because it opened up the possibility of a democratic political system and a more accountable political culture that could begin to challenge the devastating levels of poverty and inequality in the country. The transition to democracy, however, involved a transition to neoliberal development, including the intensification of a series of structural economic reforms imposed by the IMF and World Bank from the mid-1980s. Liberalisation and privatisation resulted in growing inequality between urban and rural areas, the decline of national industries, the removal of subsidies for the poorest, inflation and greater economic dependency (Paudel, 2009: 121; Sharma, 2006: 558; Khadka, 1993: 61). The gains of the 1990 movement and the aspirations for equality that had been generated across ethnic, gender and even class divides, were already being undermined by these reforms. If one response to growing social inequality was the establishment of NGOs, another was the emergence of the Maoist movement (Macours, 2011; Deraniyagala, 2005; Murshed and Gates, 2005). But the influx of international NGOs and the establishment of national NGOs was not only a response to reforms; NGOs were also an integral part of the reforms.

This article seeks to consider both the political economy of NGOs and the limitations of the Maoists' political theory as two important reasons for the lack of socioeconomic progress since the 1990 revolution in Nepal. There are undoubtedly other 
This is the accepted version of an article published by Sage in Critical Sociology. Published version available at: https://doi.org/10.1177/0896920517715765

Accepted version downloaded from SOAS Research Online: http://eprints.soas.ac.uk/23775/

proximate and structural reasons for the lack of progress; but the NGOs and the Maoists deserve particular consideration since both have been overwhelmingly present in Nepal's political landscape for more than two decades, and have consistently and explicitly sought to address the question of socio-economic progress. ${ }^{1}$ The article examines the relationship and the relative power dynamic between the two social forces, and specifically analyses how the NGO sector in Nepal has influenced the evolution of the left parties. ${ }^{2}$ The interaction between them, both fighting for social change according to seemingly opposing ideologies and strategies, contains at least a partial explanation for Nepal's failed development (Panday, 2009[1999]) and a political trajectory following the end of the war that has seen nationalist, patriarchal and elite, upper-caste interests strengthened. These interests were consolidated in the 2015 Constitution, which was rapidly pushed through following the earthquakes in 2015, despite already being seven years in the making. Crucially, the increase in inequality in the 1980s and 1990s has been exacerbated (Wagle, 2010: 83) and shows few signs of reversing. It is argued that the inability of the left in Nepal to capitalise on the revolutions, including during and immediately after the war, relied on the interplay of two phenomena: an anti-Maoist alliance consisting of the international community, the domestic ruling elite and NGOs, and a fundamental ambiguity at the heart of the Maoists' political theory. At a number of crucial moments, the Maoists' conviction that Nepal was not economically prepared for social transformation led to moments of hesitation and indecision. These were successfully exploited by the neoliberal state and, within a broad class alliance, the agency of NGOs. Indeed, there is a history of interventions in Nepal where NGOs played significant roles in resolving upheaval in ways that have protected elite interests and helped facilitate the incorporation of the left into conventional, mainstream politics. This phenomenon is not unique to Nepal, but has had devastating consequences in the post-war period, given the hopes generated by the revolutions over the past two decades.

Contributions analysing the impact of the development industry in Nepal since the 1990s have understood development as both a capitalist enterprise, and one that has had enormous political and ideological influence in the shaping of civil society and social movements (Seddon, 2014[2001]; Fujikura, 2013; Panday, 2011; Tamang, 2002; Des Chene, 1996; Khadka, 1993; Pigg, 1993; Shrestha, 1993). NGOs form a major component of development in Nepal. Approximately 40,000 national NGOs and 211 international NGOs are currently registered with the Social Welfare Council (SWC), and tens of thousands more are unregistered. ${ }^{3}$ This political influence, it has been argued, both structures and constrains the sorts of interventions NGOs engage in, limiting activities that explicitly counter neoliberalism and the social relations that underpin it. The rise of the Maoists and the launch of the People's War similarly prompted a vast literature analysing the causes and consequences of the war (Adhikari, 2014; Jha, 2014; Gidwani and Paudel, 2012; Hutt, 2004; Karki and Seddon, 2003). But few have presented a combined analysis of the historical and ideological relationship between the left and the NGOs (Heaton-Shrestha, 2010; Chintan, 2000), and the significance of this association in terms of the prospects for social change. This analysis takes on greater importance and is further complicated in the current context in Nepal, where the state, through the Commission for the Investigation of Abuse of Authority (CIAA), has been selectively targeting NGOs. Organisations have been accused of corrupting funds and competing with government in the implementation of development projects, particularly as earthquake funds have 
This is the accepted version of an article published by Sage in Critical Sociology. Published version available at: https://doi.org/10.1177/0896920517715765

Accepted version downloaded from SOAS Research Online: http://eprints.soas.ac.uk/23775/

poured into the country. ${ }^{4}$ Yet there are credible concerns that NGOs are being targeted not with the aim of holding them accountable but to silence opposition.

There are undoubtedly perils with any analysis of NGOs as a homogenous set of institutions. To paraphrase Panday (2011: 134), a social species as large as the NGO sector, and one that is operating in such diverse social, economic and political environments 'cannot be homogenous'. The complexities manifest themselves not only in terms of diversity of context, purpose and activity, but in the class differences of those who work for NGOs. At the same time, there must be an analysis of the sector as a whole that, while recognising the outliers that exist, can explain common features and tendencies, and identify the origins and interests of these institutions. Understanding NGOs in relation to the workings of neoliberalism and the neoliberal state facilitates an examination of NGOs not as a conspiracy, not as more powerful than states, but as 'a unified institutional totality' (Fernando, 2011: 24) that serves in various ways to legitimise and manage capital accumulation and the geopolitical interests of states. Of the many criticisms levelled at NGOs, one that stands out is being accused of weakening the revolutionary left (Choudry and Kapoor, 2013: 2; Fernando, 2011: 7; Chintan, 2000: 138; Petras, 1999: 431) by diverting potential support for structural change towards an accommodation with the neoliberal order. In a country where the NGO sector has become a veritable industry, and yet where the revolutionary aims of the Maoists had clear resonance amongst large sections of the population for a time, measuring the respective approaches of NGOs and the left, and examining the relationship between them, seems an important component of a holistic understanding of social change in Nepal.

The first section puts NGOs and the left in context and outlines a broad understanding of the relationship between them, adopting a critique of the role of NGOs that has been developed elsewhere (Hearn, 2007; Kamat, 2004). The second section describes a history of intervention in Nepal by major imperialist powers, showing that poverty reduction was subordinate to the goal of countering the growth of communism. The continuity of this subordination was evident throughout the People's War, where much of the NGO sector was working with an alliance of anti-Maoist forces, whose ideological project was to bring about an end to resistance and prevent the development of an alternative project for social transformation. The third section analyses the influence of NGOs on the Communist Party of Nepal (Unified MarxistLeninist) or UML. This is followed by the fourth section analysing the Maoists' experience with NGOs, arguing that although the Maoists developed an anti-NGO rhetoric, they failed to develop a conscious strategy of engagement with the NGOs, either on the ground or at the level of policy. Rather, they drifted into an engagement, with fatal consequences. The final section analyses the basis for the Maoists' theory of revolution, which adopts a stagist perspective that rejects social change as a concrete possibility in the present and postpones it to an unidentifiable point in the future. In this sense, the left parties share the evolutionist, gradualist approach of the NGOs, and it is this partial ideological convergence between the NGOs and the Maoists in particular that is critiqued. It should be noted, however, that while this analysis is both a critique of NGOs and the left, to borrow from Ahmad (1992: 160), it comes from a sense of solidarity with the left in Nepal and those NGO activists fighting for social change. It is hoped that this criticism contributes to further thinking through the nature of the NGO phenomenon and its relationship to neoliberalism and 
This is the accepted version of an article published by Sage in Critical Sociology. Published version available at: https://doi.org/10.1177/0896920517715765

Accepted version downloaded from SOAS Research Online: http://eprints.soas.ac.uk/23775/

imperialism. The article concludes noting the decline of radical politics in Nepal, the weakening of the left and progressive forces and the reassertion of the right.

\section{NGOs and the left in context}

Neither democracy nor development were new at the time of the 1990 revolution. Nepal had experienced democracy in the 1950s. The Nepali Congress was established in 1950 calling for armed struggle against the century-old Rana dictatorship, and won the first parliamentary elections in 1959. The Communist Party of Nepal (CPN) was established in 1949 in India and though they had less of a following, focused their energies on mobilising students, intellectuals and peasants in the capital. The Congress had barely completed 18 months in parliament when King Mahendra launched a coup, dissolving parliament, suspending the constitution, and announcing that all political parties were banned. Bringing an end to democracy, the 1960 royal coup had the backing of India and international donors, who believed the monarchy was able to provide a measure of political stability that the political parties could not deliver (Khadka, 2000: 82). These class alliances, between the domestic ruling elite and the international community, would continue to play a vital role in quelling any challenges to the existing state of affairs. The panchayat focused on distinguishing itself from the nascent political parties, which continued to gain popularity, by positing that panchayat development was of a distinctively Nepali sort that would liberate Nepal and catapult it into modernity (Des Chene, 1996: 263). The implication was, from the perspective of the panchayat, that the political parties were engaged in a form of democracy that was imported from the West.

Development activity began with the arrival of government donors in the 1950s and was promoted during the three decades of the panchayat autocracy through a nationalist programme of cultural, linguistic and religious integration. This integration nevertheless needed a practical focus that could address the material conditions of the Nepali masses; in other words, the panchayat had to prove that it could deliver concrete benefits for the vast majority (Burghart, 1993: 8), and development became the vehicle. In doing so, panchayat nationalism served to consolidate the monarchy and also distinguish it from the brutality and neglect - the glaring lack of development - of the Rana dictatorship before it. While there were important improvements in development indicators post-1950, in education, infrastructure, malaria eradication, infant mortality, communication and basic healthcare, amongst other sectors, development remained limited and uneven. Nepal also experienced a measure of economic growth and though public expenditure on development steadily increased, rising levels of foreign aid could not produce visible impacts on the poor (Parajulee, 2000: 223-4). This is because development was secondary for the panchayat. Corruption and inefficiency were rampant and the regime lacked legitimacy (Burghart, 1993); the primary project for the monarchical autocracy was facilitating national integration along specific class and caste lines.

This began to change post-1990. While there was some continuity with the panchayat era of the past, from 1990 the monarchy became restrained, and the 1990 Constitution recognised, at least on paper, the multiplicity and the rights of Nepal's ethnic and indigenous populations, the needs of the poor and the discrimination of women (Malagodi, 2013). Like other countries that experienced democratic transitions after the end of the Cold War, particularly in Eastern Europe, Nepal also witnessed the 
This is the accepted version of an article published by Sage in Critical Sociology. Published version available at: https://doi.org/10.1177/0896920517715765

Accepted version downloaded from SOAS Research Online: http://eprints.soas.ac.uk/23775/

influx and establishment of NGOs on a massive scale and the mainstreaming of 'civil society'. ${ }^{5}$ While such a prominent role for civil society asserted a space for politics, donors have supported NGOs as 'proxies for civil society' (Lewis and Kanji, 2009: 139 ) in an attempt to orient civil society towards the promotion of market values (2009: 129), whereby civil society actors are expected to conform to legal, bourgeois democratic processes that impose limits on acceptable action. Donor support for NGOs makes them easier to operationalise, monitor and control, while NGOs themselves have reinforced the notion of NGOs as constituting the whole of civil society in order to concretise their roles and identities. This is no less true in Nepal. It is precisely because of the explosive potential of civil society, however, which is implicitly recognised by donors, that civil society must be contained and, in a sense, neutralised. Appropriating the concept of civil society and popularising an interpretation of civil society as NGOs distinct from the state obstructs an understanding of civil society as a sphere of conflict and contestation, the location of hegemony as spanning both civil society and the state, according the Gramsci, and therefore that the creation of civil hegemony means a bid for seizing state power (Thomas, 2009: 194). The consequences of the fundamentally political nature of civil society are also clear in Nepal.

Prior to 1990, the activities of NGOs were co-ordinated by the Social Service National Co-ordination Council (SSNCC), in an effort largely directed at stifling opposition to the regime (Dhakal, 2007: 63). After 1990, the SSNCC became the SWC and national NGOs could obtain funds directly from international partners for the first time. The new interim government post-1990 created a task force to draw up guidelines for the NGO sector, encouraging international and national NGOs to focus on improving the lives of the most disadvantaged communities in rural Nepal (Seddon, 1993: 145). The Eighth (1992-1997) and Ninth (1997-2002) Five-Year Plans highlighted the catalytic role of NGOs in addressing poverty. Policies were adopted to extend the reach of NGOs in rural areas, encourage INGOs to work with and develop the capacity of national NGOs, develop a national monitoring and evaluation system of NGOs, simplify the administration of NGOs and ensure that the work of NGOs complimented local government (Dhakal, 2000: 88). NGOs were promoted as essential development partners, both by the state and by international donors, and quickly became established as a full-blown industry.

At the same time, having been crucial to the 1990 movement and able to openly participate in the political process after three decades of being banned, the left parties were also beginning to organise. Sections of the left, and the UML in particular, developed an orientation towards human rights (which gave them legitimacy), and social welfare (which provided a practical focus), through NGOs. This is unsurprising given that the origins of the NGO sector can be traced back to the political parties' struggle for democracy throughout the panchayat, and particularly in the 1980s. ${ }^{6}$ Another section of the left began to organise underground, following the method of armed struggle adopted by the Indian Maoists, and looking to the Revolutionary International Movement (RIM), a coalition of Maoist groups that folded in 2010. The Maoists' People's War succeeded in threatening the traditional elite by raising questions of land reform, historical discrimination against Janajatis and Madhesis and growing inequality (Ismail and Shah, 2015; Karki and Seddon, 2003). There is no question that the experience of a decade of war was brutal for both the civilian population, whether or not they supported it, and combatants alike. Almost 18,000 
This is the accepted version of an article published by Sage in Critical Sociology. Published version available at: https://doi.org/10.1177/0896920517715765

Accepted version downloaded from SOAS Research Online: http://eprints.soas.ac.uk/23775/

people were killed (Adhikari, 2014: 243) - the vast majority by the Royal Nepal Army (RNA) - thousands were injured, and infrastructure was destroyed. Despite this experience, however, the Maoists’ popularity increased. This enabled the Maoists to gain double the number of seats as the Nepali Congress in the first Constituent Assembly elections in 2008. It also put the Maoists at the helm of government in 2009 and again in 2011. ${ }^{7}$ But the particular orientation towards NGOs, developed during the course of the war, was perhaps emblematic of the flaws in the Maoists' wider strategy. The weight of almost half a century of intervention, including by imperialist powers, however, does point to the need to have exercised caution and consistency with respect to institutions that are funded and promoted by those powers.

As organisations attempting to address the problem of underdevelopment - and which arose with the ascendance of neoliberalism itself - NGOs have tended to be in a position of both challenging and working with the neoliberal state (Choudry and Kapoor, 2013: 6; Fernando, 2011: 21). Although they accept funding from international donors, they are often keenly aware of the problems generated by the economic models espoused by donors. Organisations calling for a 'rights-based approach to development', for example, oppose rights violations and advocate greater accountability for the welfare responsibilities of the state and global institutions (Fujikura, 2013: 157). The spectrum of NGOs contains a range of organisations whose aims and activities are vastly diverse, including service-delivery, advocacy, campaigning, research and policy development, amongst others (Willis, 2005: 98). NGOs have differing ideas, practices, strategies and motivations, and they make alliances with organisations and movements that span a range of ideologies. Their political positions are correspondingly diverse. There are those organisations that work to neutralise opposition and effectively promote 'the thinking of the imperialist strategists' (Petras, 1999: 440); there are also NGOs that exhibit none of these features, have diverted funds towards challenging the status quo, and have developed a critique of neoliberalism and of the donors that fund them. ${ }^{8}$

Nevertheless, the NGOs as a sector are collectively unable to translate any critique into a challenge serious enough to counter the neoliberal development promoted by the donors that fund and sustain them. Donor funding endures as a major intervention in the form and trajectory of global development. Funding is not merely a series of financial transactions that flow from developed to developing or from government to non-government; funding by powerful states creates what Gramsci (2011: 53) refers to as the 'material structure of ideology' consisting of institutions and organisations whose task it is to influence common sense. NGOs form part of this material structure, managing social change within acceptable limits determined by the state and market interests. If 'the role of NGOs in creating and sustaining social change is best understood in terms of their relationship with the state' (Fernando, 2011: 233), and in particular the neoliberal state, then the approach of NGOs is at the very least conditioned by the neoliberal state's material and ideological reinforcement. Both aspects of support, material and ideological, are crucial since even where NGOs refuse government funding on principle they operate within the ideological boundaries set by the state - 'the formidable complex of trenches and fortifications of the ruling class' (Gramsci, 2011: 53). Gramsci further emphasises the importance of analysing 'how the ideological structure of a ruling class is actually organised: that is, the material organisation meant to preserve, defend, and develop the theoretical or ideological "front"' (2011: 52), in order that the 'forces of agency in society [can be 
This is the accepted version of an article published by Sage in Critical Sociology. Published version available at: https://doi.org/10.1177/0896920517715765

Accepted version downloaded from SOAS Research Online: http://eprints.soas.ac.uk/23775/

assessed] with greater caution and precision' (2011: 53). As the political orientation of NGOs is not arranged against the state but is rather sustained by it, the lack of consciousness of this task and their own role within the material structure influences the extent to which NGOs are able to challenge the structures they partly seek to oppose.

Both NGOs and the left identified the need to address poverty and inequality, though from very different theoretical and strategic starting points. Ultimately, neither the NGOs nor the left parties have been able to address the socio-economic problems of the vast majority or reverse the current political decline. Both have accommodated the status quo and argued, in various ways, for the need to build capitalism. The process of partial convergence with NGOs began with the UML, and continued to different degrees with the Maoists, despite their consciousness of the UML's engagement with NGOs and the subsequent transformation of the party. For the Maoists, objective economic conditions in Nepal meant that the growth of productive forces became the defining criterion for social and political development. The logic of this stagist approach was the Maoists' focus on the need for specifically capitalist development. This mirrors the NGOs' inability to challenge neoliberal development and the adoption of an evolutionist, gradualist method: the rejection of fundamental transformation in favour of an increasingly professionalised and essentially technical approach to the problems of poverty, inequality and underdevelopment (Kamat, 2003: 90; Lister, 2003: 178). It is this that defines the essence of NGOs as a category with which to analyse politics and development in Nepal.

\section{A history of intervention}

In the 1950s and 60s, according to Joshi and Rose (1996[1966]: 472), among Asian states there was perhaps none whose economic development programme was more dependent on foreign assistance than Nepal's. For the two largest donors at the time, the US and India, aid was determined by 'standard, Cold War thinking' (Brown, 1996: 64). For India, Nepal was considered to be vulnerable to the influence of China's communist revolution, and through which communist ideas could spread to India. For the US, economic development for its own sake was not a priority. From the late 1940s the debate about foreign aid in the US was linked to the leverage that aid could have in realising strategic interests, and aid has figured heavily in US foreign policy since the Second World War (Hayter, 1971: 87). The effective overthrow of the Rana regime in 1950-51, combined with the perceived threat of communism following the Chinese Revolution, led the US to establish a presence in Nepal, even before Russia and the regional powers India and China (Skerry et al., 1992: 1). Khadka (2000: 77) argues that there were two primary reasons for the US initiating the General Agreement for Technical Co-operation with Nepal in January 1951: the growing popularity of communist parties in South Asia in general and Nepal in particular and, second, the grinding poverty found across Nepal. Bringing about the end of the Rana regime was evidence that Nepalis wanted a change in their living conditions, reasoned US officials; but equally, the US believed that aid could prevent people from turning to communism to address social problems, and also prevent Nepal from becoming a focal point for communist activity. If aid could help Nepal experience rapid economic growth, it would be able to repel any communist influence from either China or the various communist groups in India, and even the Soviet Union. In US foreign policy circles, the 'vulnerability of the peasantry' (Mihaly, 
This is the accepted version of an article published by Sage in Critical Sociology. Published version available at: https://doi.org/10.1177/0896920517715765

Accepted version downloaded from SOAS Research Online: http://eprints.soas.ac.uk/23775/

1965: 31) to communism was widely considered to be the greatest threat to stability in Nepal.

If US assistance to Nepal in the 1950s began with the objective of containing communism, and the strategic element of US foreign policy was de-emphasised in Nepal from about the mid-1970s (Khadka, 2000: 89), the question remains as to what extent the US continued to be concerned with communist activity in Nepal, and the methods by which they addressed these concerns. Khadka (2000: 93) remarks that 'although the US failed during the Cold War in its objective to prevent the growth of communism, this objective will continue to guide US foreign policy for some years to come'. Indeed, even without Cold War politics dominating US foreign policy from the 1990s, aid has continued to be used for economic and political interests. With the UML's election victory in 1994 and the launch of the Maoists' People's War two years later, the US remained concerned about communism fomenting political instability. During the war, the US administration took strong measures to communicate its displeasure about the political situation, including putting the Maoists on the second tier of the US terrorist list in April 2003 (despite the Maoists joining a ceasefire and peace negotiations), threatening to withdraw aid, training the Nepali army and working with India (now much stronger in the region compared to the Cold War years) to bring the Maoists into the mainstream (Von Einsiedel et al., 2011). USAID and other donors also funded NGOs to propagate the idea that the conflict in Nepal was the central obstacle to development, as opposed to being the product of an attempt to redress inequality, and that it was virtuous to remain neutral during the conflict (Save the Children, 2008: 18). ${ }^{9}$

The facts on the ground suggest that the longstanding goals of US development efforts largely failed, and generated the conditions for the Maoists' revolt (Paudel, 2016). But the situation is not unambiguous. On the one hand, the communist movement had been a growing force from the 1950s onwards, and Nepal elected its first communist government in 1994; the Maoists launched the People's War in 1996 - the most concerted movement against the state in Nepali history - and since 2008 either the UML or the Maoists have been in government, apart from a stint by the Nepali Congress lasting less than a year. Perhaps most importantly, a consciousness has been developed amongst the mass of the population, both in response to early development projects and in response to neoliberal development and the social inequality that it gave rise to (Paudel, 2016; Shneiderman, 2009). ${ }^{10}$ Thus communist influence has arguably strengthened over the past 60 years, not waned. On the other hand, an antiMaoist alliance between international and national forces did manage to consolidate itself in the post-conflict context, with the assistance of the US. Though the objective of anti-communism remained the same, the form through which it was conducted changed: with plans from the early 1990s to significantly expand funding to NGOs (Skerry et al., 1992: 358), engagement through NGOs became a major pillar of US assistance. $^{11}$

Of course, USAID was never the only donor funding NGOs. There have been several major periods in recent Nepali history in which the numbers of NGOs grew dramatically; first, following the 1990 revolution; second, following the escalation of the conflict in 2001; third, following the 2006 revolution; and finally, following the earthquakes in 2015. The focus of funding in the early 1990s was infrastructure development, and only in the mid-1990s expanded in a more strategic manner to 
This is the accepted version of an article published by Sage in Critical Sociology. Published version available at: https://doi.org/10.1177/0896920517715765

Accepted version downloaded from SOAS Research Online: http://eprints.soas.ac.uk/23775/

include advocacy around human rights and social inclusion. Following the escalation of the war in 2001, a number of NGOs working on peacebuilding and conflict transformation became more prominent. Although these NGOs could not work beyond district headquarters during the war, funding for peacebuilding projects was ample and extensive. Following the 2006 revolution, new organisations emerged that were working on constitutional issues, transitional justice and security sector reform, in addition to peacebuilding, and more INGOs working on these issues were also registered. ${ }^{12}$ As Miklian et al. (2011: 297) argue, 'foreign aid for peacebuilding tends to arrive in large volumes just after conflict'. These organisations have had access to funding on an even grander scale than previously. The thrust of donor efforts was to bring an end to the Maoists' war, and the threat was that they would otherwise pull out of development projects. There were genuine security concerns that were cited. But the precondition was always to end the war in exchange for development, regardless of the fact that limited development was arguably the reason for the war in the first place. Finally, US\$4.1bn was donated following the 2015 earthquakes. ${ }^{13}$ NGOs raised a massive amount of funding on their own and accessed a share of donor funds. ${ }^{14}$ It has been suggested that reconstruction has opened up possibilities for the reinforcement of neoliberal development in the manner of disaster capitalism (Simpson and Serafini, 2015), but a clearer picture has yet to emerge.

\section{The UML's concerted policy turn}

As the communist parties were celebrating the end of the panchayat era, they also had to contend with new realities following the end of the Cold War, causing intense debate within the movement. The communists themselves had recognised the need to assert their continued relevance in a context where a global consensus seemed to be emerging about the ostensible victory of capitalism over communism, and when Russia and to some extent China were adopting neoliberal economic policies. As Hoftun et al. (1999: 238) put it, 'the communists desperately needed to defend an ideology which was manifestly dying elsewhere in the world and show that it was still politically viable for Nepal'. This is particularly true for the UML, being the biggest left party and the main opposition party. Its emergence, evolution and ideological orientation - including how it came to embrace NGOs - deserve some consideration.

Amidst the fragmentation of the original CPN, which began over the Sino-Soviet split of the early 1960s, there was also a series of mergers over the years. The most significant merger immediately after the 1990 movement was the between the CPN (Marxist-Leninist) and the CPN (Marxist), to form the UML. The CPN (ML) was established in 1978 and had its roots in the 1971 Jhapa rebellion, which was directly influenced by the birth of the Indian Maoist movement in 1967 in Naxalbari. It dominated the 1979 student movement but also began to work underground in several districts across the country in the late 1970s and 1980s, setting up 'base areas' and developing a network of support (Shneiderman, 2010: 50). Villages were chosen on the basis of two factors: the density of landless, agricultural labourers and poor peasants, and the remoteness of the area from urban centres (Hachhethu, 2002: 59). During that time CPN (ML) cadres undertook the patient work of organising amongst villagers. Although the party had made a decision to distance itself from its Naxaliteinspired origins shortly after its formation, replacing the tactics of armed revolution with building front organisations following the defeat of the Jhapa rebellion (2002: 61), CPN (ML) cadres continued to be treated as terrorists by the panchayat regime 
This is the accepted version of an article published by Sage in Critical Sociology. Published version available at: https://doi.org/10.1177/0896920517715765

Accepted version downloaded from SOAS Research Online: http://eprints.soas.ac.uk/23775/

(Shneiderman, 2009: 295). According to Hachhethu (2002: 61), the CPN (ML)'s strategy was characterised by 'organisational flexibility, penetration, nonconfrontation, and maximisation of political space'. Shneiderman (2009) shows how in the village of Piskar in the eastern district of Sindhupalchowk, CPN (ML) cadres were successful in using this strategy to introduce communist ideas and produce a heightened political consciousness. But by the late 1980s the CPN (ML) had already accepted the idea that 'conventional multiparty democracy could be a stage on the road to achieving naulo janabad [new people’s democracy] (Hoftun et al., 1999: 238) because of the 'semi-feudal, semi-colonial' nature of Nepal. While the UML was historically one of the most popular communist parties in Nepal, its rightward shift generated disillusionment amongst its supporters, leaving them open to Maoist recruitment in the late 1990s (Shneiderman, 2010: 47). One of the sources of this shift was its engagement with NGOs; in turn, the transformation of the UML allowed NGOs to hegemonise civil society space in Nepal.

There is a widespread perception in Nepal that the UML is linked to the majority of NGOs in the country, including the largest and most influential NGOs. This perception has been cultivated over a number of years and is not unfounded. It is discussed in the mainstream media, and the UML leadership is cognisant of this association. ${ }^{15}$ Post-1990, when NGOs became far more closely allied with foreign donors and foreign funding than previously, the left parties had to make decisions about how to engage with them. The UML decided to embrace NGOs in order to deal with some of the pressures it faced, both in government and as a communist party in opposition. Thus the establishment of NGOs was a deliberate, strategic move on the part of the UML. Senior leaders within the UML acknowledge this, arguing that 'as a political party [the UML] is very near to NGOs... because we sent some of our good cadres to start the NGO movement'. This particular leader also conceded that in the early 1990s 'the UML strategically set up NGOs', dividing cadres into different sectors and ensuring that NGOs were working according the principles of the UML. ${ }^{16}$

There were arguably three main reasons for the development of these links, which relate to both internal and external pressures on the UML as it consolidated its position in the parliamentary landscape. First, the UML needed to reinvent itself as a viable electoral alternative with a relevant ideology. While the Nepali Congress came to be fully accepted by the donor community, the UML still faced the stigma of being a communist party. It responded by adopting a human rights discourse that allowed it to cultivate links with the international community and NGOs, and create a perception that it was a communist party willing to modernise itself. It also became a champion for the signing of a number of international human rights treaties. This put pressure on the Nepali Congress, because the UML could then use international human rights treaties to criticise Congress policies. Members of the UML leadership were not always comfortable with this policy. Some were conscious that NGOs were not neutral organisations, and possessed a critique of NGOs and donors, which they argued were likely to conflict with the interests of ordinary Nepalis. ${ }^{17}$ Younger leading members of the party go further and have argued that if the UML is to have an orientation against neoliberalism it must also fight an ideological and practical campaign against NGOs, and ensure that younger comrades understand the role and influence of NGOs. There is also a perception that donors use NGOs to deliberately disorientate opposition movements. Not only are they are accused of defusing these movements at an organisational level, but also of disarming them at the level of 
This is the accepted version of an article published by Sage in Critical Sociology. Published version available at: https://doi.org/10.1177/0896920517715765

Accepted version downloaded from SOAS Research Online: http://eprints.soas.ac.uk/23775/

theory: 'We need to make young people more ideological, and the next generation will definitely be anti-NGO. The issues revolutionary communist parties raise, the NGOs are now raising. This is confusing people. To defuse the revolution [sic], they [donors] deploy NGOs... There is a lack of clarity about NGOs on a theoretical level and what they are trying to do'. ${ }^{18}$ The contradiction between this consciousness and the practice of the UML can be explained by understanding the wider pressures they faced as a party post-1990. The contradiction was resolved by employing a pragmatic but essentially defeatist approach. Working with NGOs would provide two major assets for the UML: funding, which was necessary for the fledgling party, and an ideology that was backed by the international community. Since many UML members worked for the party full-time, unlike Congress members, the party needed funds to pay these workers. Developing links with international human rights organisations for projects in Nepal meant that the party could potentially draw on these funds.

The second major advantage of the UML's relations with NGOs concerned its roots in Nepali society. As it was almost always in opposition and rarely leading government, the UML needed to develop an alternative support base at local levels to rival the Nepali Congress. Following the 1990 revolution, the Nepali Congress accepted many former panchayat politicians as members, and grew to be the biggest and most influential party in Nepali politics. The UML developed its own base of support by working through the NGOs both at local levels and in Kathmandu through networks across the country. ${ }^{19}$ Another senior member of the UML has argued that 'in the beginning when the NGOs came to Nepal, they hired UML people, UML cadres. They were NGO-paid [party] workers. Because they had the capacity to go the people, they had a base... They were in the [NGO] movement from the beginning'. The UML's cadres were also described as being 'masters of NGOs'. ${ }^{20}$ Again, despite the contradictions this involved, the development of this base was important for the UML as a left-wing party aiming to represent the interests of the poor. There was a determination that these links would withstand the pressures associated with donor funding.

Finally, the factional dynamic within the party over the relationship with NGOs served to strengthen the conservatism that developed in the 1970s. Moderate forces inside the UML had long faced pressures from the more radical communists over various aspects of its political vision, in particular its support for constitutional monarchy and what this meant for the transition to socialism. The resources and the ideological support provided by NGOs were invaluable to ensuring that those leaders arguing for peaceful social transformation came to the fore. The evolution of communist parties into moderate, centrist parties is a common story, but in Nepal it has been a story with NGOs at its core. Through the mediation of NGOs, Nepal's perceived dependence on international aid and the apparent necessity to attract foreign investment has helped ensure that the UML gradually compromised its radicalism, and consolidated its ideological shift rightward. This was not an uncomplicated process or a clear case of 'co-option' by NGOs, since a number of UML cadres have a considered critique of the NGO industry. But it does reveal the more subtle forms that imperialism can take, including 'soft imperialism' (Davis, 2006: 75-76), and where NGOs have become indigenised but continue to work in the interests of international capital (Hearn, 2007: 1099). At the very least, this points to the need for the left to recognise and devise strategies for dealing with them. 
This is the accepted version of an article published by Sage in Critical Sociology. Published version available at: https://doi.org/10.1177/0896920517715765

Accepted version downloaded from SOAS Research Online: http://eprints.soas.ac.uk/23775/

\section{The Maoists' pragmatic drift}

The Maoists were conscious of the UML's transformation, and instituted a relatively determined anti-NGO policy in strategic base areas during the People's War. Unlike the UML, however, the Maoists' engagement with NGOs was less a conscious policy turn. What they shared with the UML was the adoption of a pragmatic position driven by circumstance and the range of economic and political pressures that were brought to bear on them towards the end of the war. The Maoists' demand concerning NGOs, stipulated in their initial 40-point document issued to government in 1996 when they launched the People's War, stated that the work of NGOs and INGOs was equivalent to 'bribing by imperialists and expansionists' (Karki and Seddon, 2003: 184) and must be stopped. Later, in 2001, they warned that 'imperialist financial penetration and internal sabotage on the pretext of NGOs/INGOs shall be ended'. ${ }^{21}$ Various party documents also refer to the role of NGOs, and there is certainly evidence of concerted reflection about this role. One document states that 'under the strategy of preventing revolution in a country like ours the networks of NGOs and INGOs have been spread in order to engage some educated middle class people, to prevent them from falling below the middle class and to entrap the people in the petty reformist mirage' [sic] (UCPN 2004: 17). Thus at the broad policy level there was a clear identification of NGOs as hostile actors and there was clear opposition towards their perceived role. The practice, then, at least for a period during the war, was to ban or at least oversee NGO activity in areas under their control. This applied particularly to the Maoists' base areas but theoretically to the country as a whole. Thus the Maoists' hostility towards NGOs - as 'foreign imperialistic spy agencies' merely providing jobs 'to the relatives of Nepali Congress, the UML and other influential people' (Kattel, 2003: 66) - had been a defining characteristic of Maoist rhetoric since the beginning of the war. But since much of the population relies so heavily on NGO projects, it was always extremely important for both the Maoist leadership and the party's cadre to analyse the role of NGOs and at the same time present a coherent alternative to what were widely perceived as the failures of NGOs.

Part of the problem, however, was that the policy was only ever enforced in a partial and unsystematic manner. At the local level, for example, Shneiderman and Turin (2004: 101) note that some organisations were forced to leave based on the Maoists' perception of corruption amongst NGOs, but others were allowed to remain; the merits of particular NGOs were evaluated on a case-by-case basis. The other part of the problem was pressure at the international level, where donor support for NGOs began to influence the trajectory of the Maoists' own position. Towards the end of the war, in 2005 according to one source, the Maoists began to make the distinction between 'hardware' and 'software' projects, mimicking a similar distinction made by NGOs themselves. ${ }^{22}$ Hardware projects included building roads and infrastructure tangible projects that had the potential to directly benefit people; whereas software programmes were ideological, and could include work around social exclusion, youth training or human rights work. Members of the people's government, for example, had said that they could accept hardware projects in the base areas, but had to refuse human rights NGOs, missionaries or other 'ideological' projects. Shneiderman and Turin (2004: 100) also observe that the Maoists were averse to 'forms of social action', which they feared might interfere with their revolutionary activity. Some human rights NGOs in areas under Maoist control were dominated by UML activists, and operated at least partially with the aim of extending UML politics into base areas. 
This is the accepted version of an article published by Sage in Critical Sociology. Published version available at: https://doi.org/10.1177/0896920517715765

Accepted version downloaded from SOAS Research Online: http://eprints.soas.ac.uk/23775/

The same observer explained that the Maoists 'know that through NGOs, the UML is doing politics - that is why they don't want to allow them [into base areas] - they don't want competition against their organisation. They are very much afraid if they permit NGO activity freely, then... these UML NGOs... will work as party workers... There isn't a deeper ideological reason'. ${ }^{23}$

The policy on NGOs, however disjointedly applied, has remained in place for more than a decade since the end of the war, with sections of the Maoist leadership arguing that the way to counter the hundreds of NGOs dominated by the UML at the local level was to engage with NGOs themselves. The argument went that they would work in a transparent manner, only solicit funding for hardware projects and work with donors that have no 'hidden interests'. ${ }^{24}$ It is arguable that the reason the Maoists began increasing their engagement with NGOs towards the end of the war - not unlike the UML - was based on pragmatism. If money and resources continued to pour into Nepal during the war, at least some of which was targeted at base areas, then the Maoists wanted access to these resources. The simple fact that a large amount of aid was targeted in the base areas made maintaining a hard line on NGOs very difficult. The temptation was to engage with NGOs to try and control their activities. But this acceptance of the need to deal with NGOs as part of the political and economic landscape, similar to the one adopted by the UML in the early 1990s, was based on the notion that NGOs could be used to divert funding in order to further the aims of the party. Instead, it became the beginning of a longer-term approach to the question of NGOs, one that was more accommodating than antagonistic.

A growing acceptance of NGOs in practice also influenced the ideological orientation of the Maoist leadership. Two examples stand out. The first is the way the leadership approached and conducted themselves during peace talks with the government in 2003. Even at this time, a general softening of the Maoists' position towards NGOs was evident, and was part of an emerging tendency to try and draw NGOs into the struggle for democratic change. The Maoists began to make public statements in the media calling on NGOs to press the government for dialogue and to investigate human rights abuses. In this context, the Maoist leadership had begun to see NGOs as potential allies in exposing the human rights abuses of the army. In turn, this helped increase the legitimacy of NGOs in the peace process, even as mediators. NGOs began to play a peace-brokering role, and donors began to promote the role of NGOs and civil society in the peace process. The Maoist leaders - still officially underground at this time - publicly and privately met the heads of national and international NGOs in Kathmandu, where they had gathered for the talks. Soon enough the discourses of 'peace', 'conflict resolution' and 'development' dominated the negotiations, displacing earlier Maoist ideas of economic demands, structural change and social justice. Maoist leaders often asked civil society leaders for their advice on the way forward for the party. The slogans adopted by NGOs, donors and the mainstream parties around the 'politics of consensus' entered the vocabulary of the Maoists and began to heavily influence their strategy and thinking. The Maoists had argued that the UML's experience with NGOs damaged the whole of the left, and compromised Nepal's national identity and culture. ${ }^{25}$ But the Maoist leadership's own position on NGOs shifted from one that viewed all NGOs as detrimental to the interests of Nepal's poor, to a pragmatic one that not only accepted but also facilitated the work of NGOs. While this position confounded the Maoist rank and file, it 
This is the accepted version of an article published by Sage in Critical Sociology. Published version available at: https://doi.org/10.1177/0896920517715765

Accepted version downloaded from SOAS Research Online: http://eprints.soas.ac.uk/23775/

allowed NGOs a great deal of freedom and the basis on which to establish their models of development as the common sense of progressive politics.

The second, and perhaps even starker example, was the general strike of 2010 called by the Maoists, in which hundreds of thousands of people participated. The strike had been called as indefinite, but lasted for five days, with mass demonstrations, mass meetings in the streets and all transport and shops closed down. At times, the strike appeared to have relatively far-reaching aims, threatening to go beyond the terms that had been set by the 2006 Comprehensive Peace Accord (CPA) and raise fundamental social and economic questions. But on the sixth day, major NGOs and professional associations mobilised tens of thousands supporters in opposition to the strike. Their demand was that the Maoists end the strike within 48 hours on the grounds that it was disrupting the peaceful functioning of the city and was detrimental to the peace process. The ultimatum they gave the Maoists was that they would come back out onto the streets in even greater numbers. They did not have to wait long. Not only did the Maoists withdraw the strike that very evening, Chairman Prachanda publicly apologised four days later, calling for national consensus. Much of the Maoist rank and file were seething.

While the Maoists' position on NGOs soon became scarcely distinguishable from the other mainstream parties, the exact mechanisms through which this transformation took place were complex. The absence of a record of open debate within the party over the question of NGOs, however, confirms the impression that there was not a considered reorientation of the Maoists' approach to NGOs, but rather a fragmented evolution. The evidence suggests that the Maoists drifted into a pragmatic engagement with NGOs rather than making a concerted policy turn. There were strong pressures on the Maoists, ranging from economic to practical and strategic, and the consequences of this increased engagement were serious, leading as they did to the adoption and internalisation of NGO discourse, and arguably certain theoretical concepts of the NGOs. But the very fact that such a transformation on a question as central as the attitude to NGOs was largely driven by circumstance and pragmatic considerations raises questions about the coherence of the Maoists' theory in the first place. It suggests that hostility towards NGOs had been based on a largely rhetorical and underdeveloped argument: NGOs are agents of imperialism with no redeeming features, only crude vessels for propagating the interests of foreign donors. In reality, the role of NGOs has been much more contradictory, and the Maoist leadership's onesided argument was never going to provide an adequate guide for what would necessarily involve a complex strategy. Having begun from a revolutionary perspective, one in which popular agency was central, the Maoists moved closer to an NGO approach to social change on entering parliamentary politics. This involved conceptualising the potential for social change through direct human agency as limited to the political field, and conceiving economic policy as essentially a collection of technical measures whose main aim is the nurturing of free enterprise. ${ }^{26}$ This was not an uncomplicated acceptance of intervention, but is worth considering in the context of the political theory adopted by the Maoists - and many other communist parties - that partly led them to this position.

\section{Postponing social change}


This is the accepted version of an article published by Sage in Critical Sociology. Published version available at: https://doi.org/10.1177/0896920517715765

Accepted version downloaded from SOAS Research Online: http://eprints.soas.ac.uk/23775/

The basis for these shifts is a theoretical framework that is predicated on postponing social change. There are both subjective and objective factors at play here: it is both the case that the objective situation - Nepal's geopolitical position, its relationship to India and the US, its terrain and level of underdevelopment and so on - that convinced at least some Maoists that NGOs are a necessary evil; but the left parties' analysis of the political economy of Nepal, their focus on development as a nationalist project, and their acceptance that the degree of economic development determines the level of consciousness of the Nepali working class, also made them vulnerable to the influence and ideas of NGOs. There were many communists - even from the early days of the panchayat - who had felt that working within the system was the best way to achieve their goals (Hoftun et al., 1999: 235). Several communist parties professed not a dictatorship of the proletariat but an alliance between classes - in particular the peasantry and the national capitalists, in the absence of a large industrial working class. In practice, this alliance was meant to operate under the leadership of the communists themselves (Hoftun et al. 1999: 235). This interpretation would lay the foundation for unity and moderation; it became the strategy for large sections of the communist movement, and they would be rewarded with positions of power.

Consequently, the left parties in Nepal have traditionally argued that socialism is only possible in the distant future, a position based on a theory of stages.

An analysis of the stagist theory and its consequences is essential for understanding the character and potential for socialist revolution in the context of developing economies with large peasantries. While it was the Maoists who had recognised the objective possibility of fundamental social change, they were also the most vocal in calling for a transition to capitalism as the first stage towards that goal. This call was based on an analysis of Nepal's political economy as semi-feudal and not capitalist, pointing to subsistence-based agriculture, limited wage labour and the widespread existence of private usury in rural areas by owner/cultivators (Bhattarai, 2003) as evidence for the predominance of semi-feudal relations. Bhattarai (2003: 137), widely known as a leading ideologue of the party, had explicitly argued that 'there is no doubt that the semi-feudal relation remains the principal and determining relation, both qualitatively and quantitatively'. Indeed the Maoists' use of the stagist theory as the basis for the People's War had been explicit, and they have repeatedly argued that Nepal cannot move forward without the development of productive forces under capitalism (Bhattarai, 2003). ${ }^{27}$ This theoretical approach, however, opened itself up to the possibility of a conceptual convergence with NGOs. The Maoists' theoretical analyses were complex and evolving, but one central theme was that despite the problems generated by the history of capitalist evolution in developing countries, socialism was impossible in countries with a low technological and economic base, and therefore capitalist development in the short-term was not only possible, but also necessary and desirable. NGOs clearly share the assumption that there is a problem with purely free market models of development - their very existence is witness to this. Nevertheless, if at times only in a negative sense, NGOs have accepted the framework of the market as the only practical terrain on which to pursue development. The partial ideological convergence between the NGOs and the Maoists meant that ultimately, it ceased to be the Maoists who were shaping the method of resistance, but rather the imperialist powers and the middle classes.

\section{Conclusion}


This is the accepted version of an article published by Sage in Critical Sociology. Published version available at: https://doi.org/10.1177/0896920517715765

Accepted version downloaded from SOAS Research Online: http://eprints.soas.ac.uk/23775/

The two decades after Nepal's first democratic revolution in 1990 have arguably been the most momentous period in Nepali history. There is a great deal of disillusionment felt as a result the People's War, both in terms of the death and destruction it caused, but also the potential that was lost. Part of the process by which the Maoists were ultimately integrated into mainstream politics was through an anti-Maoist alliance that included NGOs. This is not to argue that the Maoists' shift was solely down to NGOs. But it is to argue that post-1990, international donors and the dominant imperial powers amongst them, used the institutional form of the NGO as one of the main mechanisms for a wider anti-communist project. This project began much earlier and more explicitly in the post-1950 context in the form of bilateral aid, led by the US. Despite the best efforts of the US and of funding, however, the left in Nepal thrived and grew, and perhaps witnessed the height of its popularity during the People's War and the immediate post-war period. The promulgation of the 2015 Constitution confirmed the confidence of the traditional elite to continue to pursue neoliberal reforms, particularly in the wake of the earthquakes. There is resistance to these reforms, and Madhesi and Janajati parties are protesting the intolerance and discrimination of the 2015 Constitution. But there are currently no political alternatives that are uniting across ethnic divides and furthering a class project. The popular aspiration the Maoists expressed for a more humane, democratic, equitable and just society were contained by a successful counter-hegemonic struggle involving NGOs, a struggle that was facilitated by the weaknesses in the Maoists' own theory. The challenge of producing a theory and practice of development that genuinely benefits the masses of Nepal remains urgent. 
This is the accepted version of an article published by Sage in Critical Sociology. Published version available at: https://doi.org/10.1177/0896920517715765

Accepted version downloaded from SOAS Research Online: http://eprints.soas.ac.uk/23775/

\section{Notes}

${ }^{1}$ Accounting for the lack of socio-economic progress must also include an appreciation of the geopolitics of the region. Nepal's relationship with India is particularly significant, since Nepal's integration into the global economy is largely the result of its integration with and dependence on the Indian economy and it has been widely argued that this integration has undermined Nepal's economy (Rana, 1971: 652; Khadka, 1998: 157; Karmacharya, 2001: 89). India’s superior infrastructure, technology and skills, its monopoly of access to the sea and the movement of labour and goods across the long, open border have created a widening trade deficit and a level of competition that is unsustainable for Nepal. As the region's hegemon, Indian interference in Nepal's domestic affairs - from the transition to the panchayat to the restoration of democracy to the Maoist insurgency (Mishra, 2004: 628) - has ensured the continued subordination of Nepal to the political and security interests of India. See also Ismail (2015) for a fuller discussion of geopolitics as it relates to Nepal, including the role of China and US imperialism.

${ }^{2}$ Due to space limitations, only the two main left-wing parties, the UML and the Maoists, who have dominated the mainstream political landscape since at least the past 15 years, will be included in this analysis. The Maoists warrant particular attention because the People's War put social change onto the political agenda in a more forceful way than any other left-wing party in Nepal's history.

${ }^{3}$ Available: http://www.swc.org.np/?p=456 (Accessed on 2 November 2016). There are ongoing discussions between the Ministry of Women, Children and Social Welfare and other relevant ministries about replacing the 1992 Social Welfare Act to ensure greater regulation and co-ordination, and in order that NGOs and INGOs can deal with a single ministry.

${ }^{4}$ See http://www.spotlightnepal.com/News/Article/CIVIL-SOCIETY-Evil-DealNepal-

${ }^{5}$ The US contribution to NGOs was $\$ 490 \mathrm{~m}$, more than bilateral aid (Parajulee, 2000: 225).

${ }^{6}$ Heaton-Shrestha (2010: 212) notes that under the panchayat, those who wanted to work for the poor through NGOs were seen as communists; the identification of NGOs with communist parties was already widespread.

${ }^{7}$ It should be noted that the Maoists came a distant third in the second Constituent Assembly elections in 2013, securing a mere 80 seats, down from 220 in 2008. They have since been losing popularity because of their inability to deliver on promises and perceived corruption, but also because of alliances with India.

${ }^{8}$ See, for example, Onta (2011), who argues that certain independent academic NGOs are, in fact, able to maintain a great deal of editorial control over research and outputs, despite being funded by international donors.

${ }^{9}$ One lengthy report submitted to USAID by Save the Children entitled 'Strengthening the NGO Sector in Nepal to Mitigate the Impact of the Maoist Conflict' praises a Save the Children US training programme claiming, amongst other things, that it 'educated [local organisations] on how to deal with the conflict situation in Nepal, which has specifically curtailed the mobilisation of communities for most development programmes (except to fulfil the Maoist's own agenda)' (Save the Children, 2008: 18). It goes on to describe how 'participants found that the training taught them to be transparent and remain neutral during the period of conflict'. 
This is the accepted version of an article published by Sage in Critical Sociology. Published version available at: https://doi.org/10.1177/0896920517715765

Accepted version downloaded from SOAS Research Online: http://eprints.soas.ac.uk/23775/

${ }^{10}$ Paudel (2016: 1027) argues that USAID’s Rapti Integrated Development Project (RIDP), for example, which was implemented from the 1970s, was both successful in generating the desire for development amongst people in the region, but simultaneously 'proved instrumental' in the development of a consciousness that led to those same people becoming the backbone of the Maoist People's War in the 1990s.

${ }^{11}$ For that latest development in US funding to NGOs, see https://www.usaid.gov/nepal/press-releases/apr-15-2016-us-government-awards-ngos121-million-new-development-programs and the new Civil Society: Mutual

Accountability Project, also funded by USAID: https://www.fhi360.org/projects/civilsociety-mutual-accountability-project-csmap

${ }^{12}$ See CK Lal for a polemic on foreign interference in the form of 'conflict tourism': http://nepalitimes.com/news.php?id=12409\#.V-aPHj4rIy4 and http://www.economist.com/node/18895458 for the increased use of NGOs by governments in mediation and conflict resolution throughout the world more generally, including Nepal.

${ }^{13}$ See http://nra.gov.np/uploads/docs/84LdZ2BkQ8161026092851.pdf for a breakdown of funds. The National Reconstruction Authority (NRA) also notes that US\$2.7bn has been confirmed through MOUs.

${ }^{14}$ See also https://ftsbeta.unocha.org/countries/148/summary/2016.

${ }^{15}$ See http://www.revleft.com/vb/threads/114558-News-fromNepal/page28?highlight=nepal\%20bicameral\%20lame by Dipendra Jha (the article originally appeared in www.myrepublica.com but the link can no longer be accessed), and http://www.myrepublica.com/news/7701, which claims that $80 \%$ of NGOs are linked to the UML.

${ }^{16}$ Interview with PN, Kathmandu, 15 February 2010.

${ }^{17}$ Interview with PN, Kathmandu, 15 February 2010.

${ }^{18}$ Interview with RKJ, Kathmandu, 25 February 2010.

${ }^{19}$ The UML's early networks consisted mainly of students, and the party dominated the student movement of 1979. This became the basis for expanding the party, many of whom later joined the NGOs dominated by the UML.

${ }^{20}$ Interview with GB, Kathmandu, 25 February 2010.

${ }^{21}$ See http://www.bannedthought.net/Nepal/UCPNMDocs/2001/CommonMinimumPolicy-0109.pdf (last accessed on 30 March 2016). ${ }^{22}$ Interview with KO, Kathmandu, 25 March 2010.

${ }^{23}$ Interview with KO, Kathmandu, 25 March 2010.

${ }^{24}$ Interview with BK, Dolakha, 15 June 2016.

${ }^{25}$ The Maoists were not the only ones with the anti-NGO rhetoric. The Citizens' Movement for Democracy and Peace (CMDP) were deeply sceptical of NGOs, made it very clear they were not an NGO, and refused to accept funding from donors for fear this would undermine and projectise the movement. The CMDP was led by a number of well-known figures in Nepal, many of whom had themselves founded NGOs, but who wanted to dissociate themselves from what they saw as a tainted industry. The CMDP was established shortly after King Gyanendra assumed absolute power on 1 February 2005, and were pivotal to mobilising for the 2006 revolution. ${ }^{26}$ In the immediate post-war period, Baburam Bhattarai had argued that the development of Nepal's economy along capitalist lines was paramount. See: 
This is the accepted version of an article published by Sage in Critical Sociology. Published version available at: https://doi.org/10.1177/0896920517715765

Accepted version downloaded from SOAS Research Online: http://eprints.soas.ac.uk/23775/

http://old.himalmag.com/component/content/article/1104--there-is-no-reason-topanic.html

${ }^{27}$ See also http://www.asia-pacificsolidarity.net/asiapacific/focus/kantipuron_interviewwithnepalfinminister_110109.ht $\mathrm{m}$ 
This is the accepted version of an article published by Sage in Critical Sociology. Published version available at: https://doi.org/10.1177/0896920517715765

Accepted version downloaded from SOAS Research Online: http://eprints.soas.ac.uk/23775/

\section{References}

Adhikari, A. (2010) The ideological evolution of the Nepali Maoists. Studies in Nepali History and Society, 15(2): 217-251.

Adhikari, A. (2014) The bullet and the ballot box: the story of Nepal's Maoist revolution. London: Verso.

Ahmad, A. (1992) In theory: Classes, nations, literatures. London: Verso.

Bhattarai, B. (2003) The political economy of the people's war. In: Karki, A. and Seddon, D. (eds.) The people's war in Nepal: left perspectives. Delhi: Adroit Publishers: 117-164.

Brown, T.L. (1996) The challenge to democracy in Nepal: A political history. London: Routledge.

Burghart, R. (1993) The political culture of panchayat democracy. In: Nepal in the Nineties: Versions of the past, visions of the future. New Delhi: Oxford University Press, pp. 1-13.

Chintan, G.S. (2000) Foreign intervention in politics through NGOs: A case of the Left in Nepal. In: Vartola, J., Ulvila, M., Hossain, F. and Dhakal, T.N. (eds.) Development NGOs facing the 21st century: Perspectives from South Asia. Kathmandu: Institute of Human Development, pp. 134-143.

Choudry, A. and Kapoor, D. (2013) NGO-ization: Complicity, Contradictions and Prospects. London: Zed Books.

Davis, M. (2006) Planet of slums. London: Verso.

Deraniyagala, S. (2005) The political economy of civil conflict in Nepal. Oxford Development Studies, 33(1): 47-62.

Des Chene, M. (1996) In the name of bikas. Studies in Nepali History and Society, 1(2): 259-270.

Dhakal, T.N. (2000) Policy perspective of NGO operations in Nepal. In: Vartola, J., Ulvila, M., Hossain, F. and Dhakal, T.N. (eds.) Development NGOs facing the 21st century: Perspectives from South Asia. Kathmandu: Institute of Human Development, pp. 81-99.

Dhakal, T.N. (2007) Challenges of civil society governance in Nepal. Journal of Administration and Governance, 2(1): 61-73.

Fernando, J. (2011) The political economy of NGOs: State formation in Sri Lanka and Bangladesh. London: Pluto Press.

Fujikura, T. (2013) Discourses of awareness: development, social movements and the practices of freedom in Nepal. Kathmandu: Martin Chautari. 
This is the accepted version of an article published by Sage in Critical Sociology. Published version available at: https://doi.org/10.1177/0896920517715765

Accepted version downloaded from SOAS Research Online: http://eprints.soas.ac.uk/23775/

Gidwani, V. and Paudel, D. (2012) Gramsci at the margins: a prehistory of the Maoist movement in Nepal. In: Ekers, M., Hart, G., Kipfer S. and Loftus, A. (eds.) Gramsci: space, nature, politics. West Sussex: John Wiley and Sons Inc.

Gramsci, A. (2011) Prison notebooks. Translated by Joseph A. Buttigieg and Antonio Callari (Vol. 2). Columbia: Columbia University Press.

Gurugharana, K.K. (1994) Development cooperation: An appraisal of the activities of donor agencies in Nepal. In: Bongartz, H., Dahal, M.K., Aditya, A. and Dahal, D.R. (eds.) Foreign aid and the role of NGOs in the development process of Nepal. Kathmandu: Nepal Foundation for Advanced Studies, pp. 1-18.

Hachhethu, K. (2002) Party-building in Nepal: Organisation, leadership and people. Kathmandu: Mandala Book Point.

Hearn, J. (2007) African NGOs: The new compradors? Development and Change, 38(6): 1095-1110.

Heaton-Shrestha, C. (2010) Activists and Development in Nepal. In: Gellner, D. (ed.) Varieties of activism in South Asia. Delhi: Sage Publications, pp. 181-216.

Hoftun, M., Raeper, W. and Whelpton, J. (eds.) (1999) People, politics and ideology: Democracy and social change in Nepal. Kathmandu, Mandala Book Point.

Hutt, M. (2004) Himalayan 'People's War': Nepal's Maoist Rebellion. London: Hurst \& Company.

Ismail, F. (2015) Nepal, imperialism and anti-imperialism. In: Ness, I. and Cope, Z. (eds.) The Palgrave Encyclopedia of Imperialism and Anti-Imperialism. Basingstoke: Palgrave Macmillan, pp. 375-386.

Ismail, F. and Shah, A. (2015) Class struggle, the Maoists and the Indigenous Question in Nepal and India. Economic and Political Weekly, L (35): 112-123.

Jha, P. (2014) Battles of the New Republic: A Contemporary History of Nepal. London: Hurst Publishers.

Joshi, B.L. and Rose, L.E. (1996[1966]) Democratic innovations in Nepal: A case study of political acculturation. Kathmandu: Mandala Publications.

Kamat, S. (2003) The NGO phenomenon and political culture in the Third World. Society for International Development, 46(1): 88-93.

Kamat, S. (2004) The privatization of public interest: Theorizing NGO discourse in a neoliberal era. Review of International Political Economy, 11(1): 155-176.

Karki, A. and Seddon, D. (eds.) (2003) The People's War in Nepal: Left perspectives. Delhi: Adroit Publishers. 
This is the accepted version of an article published by Sage in Critical Sociology. Published version available at: https://doi.org/10.1177/0896920517715765

Accepted version downloaded from SOAS Research Online: http://eprints.soas.ac.uk/23775/

Kattel, M. (2003) Introduction to 'the People's War' and its implications. In: Karki, A. and Seddon, D. (eds.) The People's War in Nepal: Left perspectives. Delhi: Adroit Publishers, pp. 49-72.

Khadka, N. (1993) Democracy and development in Nepal: prospects and challenges. Pacific Affairs, 66(1): 44-71.

Khadka, N. (2000) US aid to Nepal in the Cold War period: Lessons for the future. Pacific Affairs, 73(1): 77-95.

Lister, S. (2003) NGO Legitimacy: Technical issue or social construct? Critique of Anthropology, 23(2): 175-192

Macours, K. (2011) Increasing inequality and civil conflict in Nepal. Oxford Economic Papers, 63: 1-26.

Malagodi, M. (2013) Constitutional nationalism and legal exclusion: Equality, identity politics, and democracy in Nepal. Delhi: Oxford University Press.

Mihaly, E.G. (1965[2003]) Foreign aid and politics in Nepal: A case study. Lalitpur: Himal Books.

Mikesell, S.L. (2001) The Maoist movement and the threat to democracy in Nepal. Himalaya, 21(1): 15-21.

Miklian, J., Lidén, K. and Kolås, A. (2011) The perils of 'going local': Liberal peacebuilding agendas in Nepal. Conflict, Security and Development, 11(3): 285-308.

Mishra, R. (2004) India's role Nepal's Maoist insurgency. Asian Survey, 44(5): 627646.

Murshed, M.S. and Gates, S. (2005) Spatial-Horizontal Inequality and the Maoist Insurgency in Nepal. Review of Development Economics, 9(1): 121-134.

Onta, P. (2011) Locating academic NGOs in the knowledge production landscape. Dhaulagiri Journal of Sociology and Anthropology, 5: 49-80.

Panday, D.R. (2009[1999]) Nepal's failed development: Reflections on the mission and the maladies. Kathmandu: Nepal South Asia Centre.

Panday, D.R. (2011) Looking at development and donors: essays from Nepal (edited by Seira Tamang). Kathmandu: Martin Chautari.

Paudel, D. (2016) The double life of development: empowerment, USAID and the Maoist uprising in Nepal. Development and Change, 46(5): 1025-1050.

Paudel, L.K. (2009) The privatisation of policy transfer: A Nepalese experience. Nepalese Journal of Public Policy and Governance, 34(1): 115-131. 
This is the accepted version of an article published by Sage in Critical Sociology. Published version available at: https://doi.org/10.1177/0896920517715765

Accepted version downloaded from SOAS Research Online: http://eprints.soas.ac.uk/23775/

Parajulee, R. (2000) The democratic transition in Nepal. Oxford: Rowman and Littlefield Publishers.

Pearce, J. (2010) Is social change fundable? NGOs and theories and practices of social change. Development in Practice, 20(6): 621-635.

Petras, J. (1999) NGOs: in the service of imperialism, Journal of Contemporary Asia, 29(4): 429-440.

Pigg, S.L. (1993) Unintended consequences: The ideological impact of development in Nepal. South Asia Bulletin, 8(1\&2): 45-58.

Save the Children (2008) Strengthening the NGO sector in Nepal to mitigate the impact of the Maoist conflict. Available at: pdf.usaid.gov/pdf_docs/PDACM273.pdf (Accessed: 2 August 2016).

Seddon, D. (1993) Democracy and development in Nepal. In: Hutt, M. (ed.) Nepal in the Nineties: Versions of the past, visions of the future. Delhi: Oxford University Press, pp. 128-164.

Seddon, D. (2014[2001]) Nepal in crisis: growth and stagnation in the periphery. Delhi: Adroit Publishers.

Sharma, K. (2006) Development policy, inequity and civil war in Nepal. Journal of International Development, 18(4): 553-569.

Shneiderman, S. (2009) The formation of political consciousness in rural Nepal. Dialectical Anthropology, 33(3-4): 287-308.

Shneiderman, S. (2010) Creating 'civilised' communists: A quarter of a century of politicisation in rural Nepal. In: Gellner, D. (ed.) Varieties of activist experience: Civil society in South Asia. Delhi: Sage Publications, pp. 46-80.

Shneiderman, S. and Turin, M. (2004) The path to jan sarkar in Dolakha district: Towards an ethnography of the Maoist movement. In: Hutt, M. (ed.) Himalayan 'People's War': Nepal's Maoist Rebellion. London: Hurst \& Company, pp. 79-111.

Shrestha, N.R. (1993) Enchanted by the mantra of bikas: A self-reflective perspective on Nepalese elites and development. South Asia Bulletin, 13(1\&2): 5-22.

Skerry, C.A., Moran, K. and Calavan, K.M. (1991) Four decades of development: The history of US assistance to Nepal, 1951-1991. Kathmandu: USAID.

Tamang, S. (2002) Civilising civil society: Donors and democratic space. Studies in Nepali History and Society, 7(2): 309-353.

UCPN (2004) Some important documents of Communist Party of Nepal (Maoist). Nepal: Janadisha Publications. 
This is the accepted version of an article published by Sage in Critical Sociology. Published version available at: https://doi.org/10.1177/0896920517715765

Accepted version downloaded from SOAS Research Online: http://eprints.soas.ac.uk/23775/

Von Einseidel, S., Malone, D.M. and Pradhan, S. (eds.) (2012) Conclusions. In: Nepal in transition: From People's War to fragile peace. Cambridge: Cambridge University Press, pp. 361-381.

Wagle, U.R. (2010) Economic inequality in Nepal: Patterns and changes during the late 1990s and early 2000s. Journal of International Development, 22: 573-590.

Willis, K. (2005) Theories and practices of development. Oxford: Routledge.

Whitfield, T. (2012) Nepal's masala peacemaking. In: Von Einseidel, S., Malone, D.M. and Pradhan, S. (eds.) Nepal in transition: From People's War to fragile peace. Cambridge: Cambridge University Press, pp. 155-174. 